\title{
Effect of Extracts of Vernonia Amygdalina in Helminthiasis- A Tropical Neglected Disease
}

\section{Ejiofor II*, Zaman K and Das A \\ Department of Pharmaceutical Sciences, Dibrugarh University, India}

*Corresponding author: Ejiofor Innocentmary Ifedibaluchukwu, Department of Pharmaceutical Sciences, Dibrugarh University, Dibrugarh- 786004, Assam State, India, Tel: +917086294160; E-mail: rs_ejiofor@dibru.ac.in

\section{Research Article \\ Volume 1 Issue 8}

Received Date: December 01, 2017

Published Date: December 15, 2017

\section{Abstract}

Soil transmitted helminths is one of the Neglected Tropical Diseases. They mainly affect the poor or the rural dwellers, but less affects the well off, because usually poor hygiene is a high risk factor. They are neglected in terms of the research and control funding allocated to them both by developing world governments and other donors. Vernonia amygdalina is being used in traditional medicine for different ailments, which helminthiasis is one. Albendazole as standard medication and methanolic crude extracts of the leaf, stem-bark and root of Vernonia amygdalina were subjected for anthelmintic activity on Adult Indian earthworm pherithima posthuma. These extracts showed potent anthelmintic activity on Adult Indian pherithima posthuma with $82.8 \pm 0.43,46.22 \pm 0.5,25.5 \pm 0.17$ as paralysis time for the leaf extract, $81.3 \pm 0.25$, $39.7 \pm 0.21,15.4 \pm 0.60$ and $39.7 \pm 0.35,31.1 \pm 0.11,13.2 \pm 0.30$ as paralysis times for the stem-bark and root extracts respectively, and $161.8 \pm 1.71,82.6 \pm 2.11,38.2 \pm 1.12$ as death time for the leaf extract, $147.5 \pm 0.81,81.70 \pm 2.01,26.4 \pm 1.13$ and $86.8 \pm 2.61,80.5 \pm 2.45,23.0 \pm 0.02$ (mean \pm S.E.M) as the death times for the stem-bark and root extracts respectively at $30 \mathrm{mg} / \mathrm{ml}, 50 \mathrm{mg} / \mathrm{ml}$ and $70 \mathrm{mg} / \mathrm{ml}$ respectively with a predicted mechanism of action. The anthelminthic activities obtained from the extracts were concentration dependent.

Keywords: Helminths; Vernonia amygdalina; Pheretima posthuma; Methanolic extract

\section{Introduction}

Neglected tropical diseases (NTDs), a diverse group of communicable diseases that prevail in tropical and subtropical conditions in 149 countries, affect more than one billion people and cost developing economies billions of dollars every year. Populations living in poverty, without adequate sanitation and in close contact with infectious vectors and domestic animals and livestock are those worst affected [1]. Some of the Neglected tropical diseases include Soil-transmitted Helminthiasis,
Schistosomiasis, Foodborne trematodiases, Human African trypanosomiasis (sleeping sickness), Leishmaniasis, Leprosy (Hansen's disease), Lymphatic filariasis [2-4].

According to Special Programme for Research \& Training in Tropical Diseases (TDR) of World Health Organization, Helminths are a broad range of organisms that include intestinal parasitic worms, (roundworms (Ascaris lumbricoides), whipworms (Trichuris trichiura), or hookworms (Necator 


\section{Open Access Journal of Pharmaceutical Research}

americanus and Ancylostoma duodenale). Infected people excrete helminth eggs in their faeces, which then contaminate the soil in areas with inadequate sanitation. Other people can then be infected by ingesting eggs or larvae in contaminated food, or through penetration of the skin by infective larvae in the soil (hookworms) [5].

In developing countries, Helminths are a large threat to public health and contribute to the prevalence of malnutrition, anemia, eosinophilia and pneumonia [6]. Most diseases caused by helminths are of a chronic, debilitating nature; they probably cause more morbidity and greater economic and social deprivation among humans and animals than any single group of parasites [7].

Chemical control of helminthes coupled with improved management has been the important worm control strategy throughout the world [8,9]. However, development of resistance in helminthes, against conventional anthelmintics is a foremost problem in treatment of helminthes diseases $[10,11]$.

Natural compounds or products from plants provide a unique opportunity in the search for new, effective, better and safe anthelmintics [12,13]. In China, for example, plant-derived medicines have been used (for centuries) to treat many disease conditions in humans $[14,15]$, and other animals, including parasitic diseases [16-18]. It is likely that many of these natural medicines may be acting on pathways in worms that differ from targets of currently used anthelmintic drugs $[19,20]$ and, therefore, might be able to kill nematodes that are resistant to one or more anthelmintics. However, for the vast majority of such natural compounds, there has been limited systematic, scientific evaluation of efficacy, mode of action and identity of their active component(s) [21-23].

Vernonia amygdalina is one of the plants in Nigeria which have been confirmed to have antidiabetic activity [24]. Vernonia amygdalina is an edible plant of the Asteraceae family. It is commonly known as bitter leaf due to its bitter taste, in Nigeria and in tropical African regions as well as in South Africa [25]. Some of its species; Vernonia cinerea and Vernonia anthelmintica are available in India. Vernonia amygdalina is known with different names in African which include Grawa (Amharic), Ewuro (Yoruba), Etidot (Ibibio), Onugbu (Igbo), Ityuna (Tiv), Oriwo (Edo), Chusar-doki (Hausa), Mululuza (Luganda), Labwori (Acholi), Olusia (Luo), and Ndoleh (Cameroon) [26,27].

Traditionally, according to Yeap SK, et al. [28] different parts of Vernonia amygdalina are used for stomach ache, gastrointestinal troubles, oral hygiene, itches, parasitic infection, ringworm, fever, headache, diabetes, tinea, cough, constipation and piles (haemorrhoids).

There had been submission that Vernonia amygdalina had been used by wild chimpanzees and gorillas for self-deparasitization [29,30]. In Ethiopia decoctions of Vernonia amygdalina have been used for cattle de-ticking [31]. Vernonia amygdalina also has been reported to have activity against Trypanosoma brucei brucei and Leishmania donovani $[32,33]$. Vernonia amygdalina contains several bioactive principles, including the sesquiterpene lactones Vernodalin, Vernolide, Hydroxyvernolide, Vernomydin and Vernodal and some novel sigmastane-type steroid glycosides Vernonioside A1, A2, B1, B2 and B3 [34,35].

Based on these ethnomedicinal uses and scientifically proven advantages, this present study was undertaken to evaluate and compare the anthelmintic activity of methanolic extracts of different parts (Leaf, stem-bark and root) of Vernonia amygdalina using adult worm.

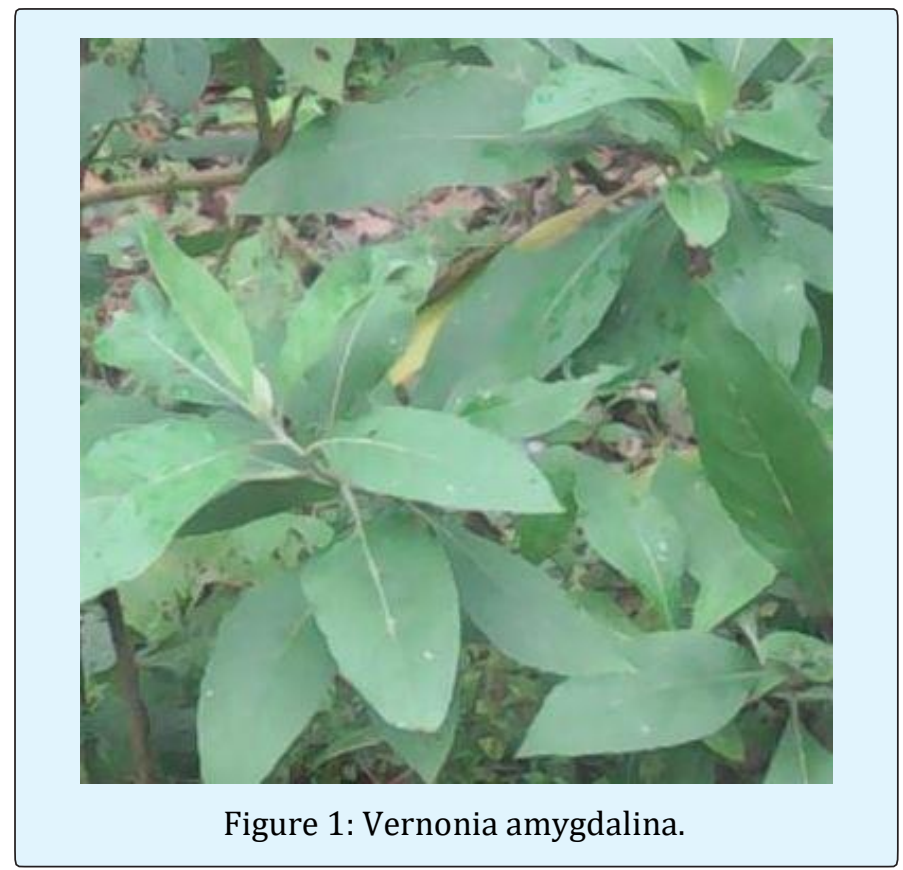

Materials and Methods

\section{Plant Collection}

The different parts of the plant, Vernonia amygdalina, were collected during the month of August, 2015, from umuono community, Ngodo village, Nise, Anambra state, Southeast, Nigeria. The plant was identified and authenticated by a taxonomist, of International Centre for Ethnomedicine and Drug Development, Nsukka, Enugu State, Nigeria. The Voucher number is INTERCEDO/041. 


\section{Chemicals and Drugs}

The Chemicals used were purchased from B.M Pharma, Dibrugarh. Hexane (HIMEDIA), Methanol (HIMEDIA), Albendazole and Carboxymethylcellulose (MERCK)

\section{Preparation of Plant Extract}

The leaves, stems and roots of Vernonia amygdalina were collected, dried under shade and powdered using a manual grinder. The parts were each subjected to successive Soxhlet extraction with Hexane and Methanol, concentrated and dried. The methanolic extracts were used for the study.

\section{Preliminary Phytochemical Screening}

Preliminary Phytochemical screening was performed using standard protocol for detection of phytochemical classes.

\section{Experimental Worms}

All the experiments were carried out on Indian adult earthworms (pherithima posthuma) due to its anatomical resemblance with the intestinal worm parasites of human being and because they are easily available and this earthworm have been used widely for the initial evaluation of anthelmintic activity of compounds in-vitro. The earthworms were obtained from Krisi Vigyan Kendra, Kaliyapani, Assam Agricultural University Jorhat District.

\section{Preparation of Administered Albendazole}

Albendazole $(30 \mathrm{mg} / \mathrm{ml}, 50 \mathrm{mg} / \mathrm{ml}$, and $70 \mathrm{mg} / \mathrm{ml}$ ) were prepared by using Carboxymethylcellulose (CMC) at $0.5 \% \mathrm{~W} / \mathrm{V}$ as a suspending agent.

\section{Preparation of Administered Plant Extracts}

Methanol Leave, stem-bark and root extracts of Vernonia amygdalina $(30 \mathrm{mg} / \mathrm{ml}, 50 \mathrm{mg} / \mathrm{ml}$, and 70 $\mathrm{mg} / \mathrm{ml}$ ) were prepared by using Carboxymethylcellulose (CMC) at $0.5 \% \mathrm{~W} / \mathrm{V}$ as a suspending agent.

\section{Experimental Protocol}

The anthelmintic activity was performed in a Petri dish. The prepared concentrations $(30 \mathrm{mg} / \mathrm{ml}, 50 \mathrm{mg} / \mathrm{ml}$, and $70 \mathrm{mg} / \mathrm{ml}$ ) of the standard drug used (Albendazole) of $10 \mathrm{ml}$ volume, were each poured into a separate a petri dish. One Adult worm each was placed into the petri dishes. The time for paralysis was noted when no movement of any sort could be absorbed except when the worm was shaken vigorously and the time of death of worms were recorded when worms neither moved when shaken nor when given external stimuli. The experiment was done in duplicate and the mean times calculated. The same procedure was used in determining the anthelmintic activities of the different concentrations (30 $\mathrm{mg} / \mathrm{ml}, 50 \mathrm{mg} / \mathrm{ml}$, and $70 \mathrm{mg} / \mathrm{ml}$ ) of the different extracts.

\section{Results}

Preliminary Phytochemical Screening

\begin{tabular}{|c|c|c|c|c|}
\hline \multicolumn{2}{|c|}{ Test } & \multicolumn{3}{c|}{ Methanol Extracts } \\
\cline { 2 - 5 } Alkaloid & Dragendorfs & + & $\begin{array}{c}\text { Steam- } \\
\text { back }\end{array}$ & Root \\
\cline { 2 - 5 } & Mayers & + & + & + \\
\cline { 2 - 5 } & Wagners & + & + & + \\
\cline { 2 - 5 } & Hagers & + & + & + \\
\hline \multirow{3}{*}{ Flavonoid } & Lead acetate test & + & + & + \\
\cline { 2 - 5 } & $\begin{array}{c}\text { Alkaline reagent } \\
\text { test }\end{array}$ & + & + & + \\
\hline Reducing Sugar & Fehlings & + & + & + \\
\hline Saponin & Forthing test & + & + & + \\
\hline Protein & Millon's test & - & - & - \\
\hline Tanin & FeCl3 & + & + & + \\
\hline Amino Acid & Ninhydrin test & - & - & - \\
\hline \multirow{2}{*}{ Steroids } & $\begin{array}{c}\text { Chloroform/ } \\
\text { Concentrated } \\
\text { Sulphuric }\end{array}$ & + & + & - \\
\hline \multirow{2}{*}{ Triterpenoids } & $\begin{array}{c}\text { Chloroform/ } \\
\text { Concentrated } \\
\text { Sulphuric }\end{array}$ & + & + & - \\
\hline Glycoside & Kellar Kiliani Test & + & + & + \\
\hline
\end{tabular}

Table 1: Result of Preliminary phytochemical screening.

\section{Result of Anthelmintic activity}

The results of the experiment are presented in Figures $2 \mathrm{~A}, 2 \mathrm{~B}, 3 \mathrm{~A} \& 3 \mathrm{~B}$. Figure $2 \mathrm{~A}$ shows the comparison of the paralysis times of the earthworms treated with the standard agent (Albendazole) and the plant extracts at 30 $\mathrm{mg} / \mathrm{ml}, 50 \mathrm{mg} / \mathrm{ml}$ and $70 \mathrm{mg} / \mathrm{ml}$ concentrations. Figure $2 \mathrm{~B}$ shows the death times covering also the paralysis times of the earthworms treated with the standard agent (Albendazole) and the plant extracts at $30 \mathrm{mg} / \mathrm{ml}, 50$ $\mathrm{mg} / \mathrm{ml}$ and $70 \mathrm{mg} / \mathrm{ml}$ concentrations. Figures $3 \mathrm{~A} \& 3 \mathrm{~B}$ shows the worms treated with the standard agent (Albendazole) and the extracts respectively, with each showing different morphological characteristics after death. 


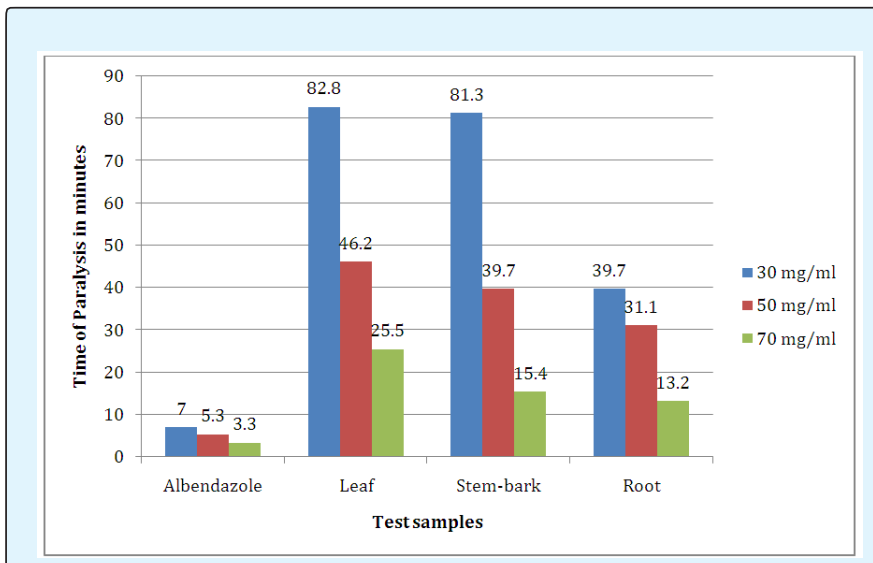

Figure 2A: Paralysis Time of the Standard and Test Samples at Different Concentrations.

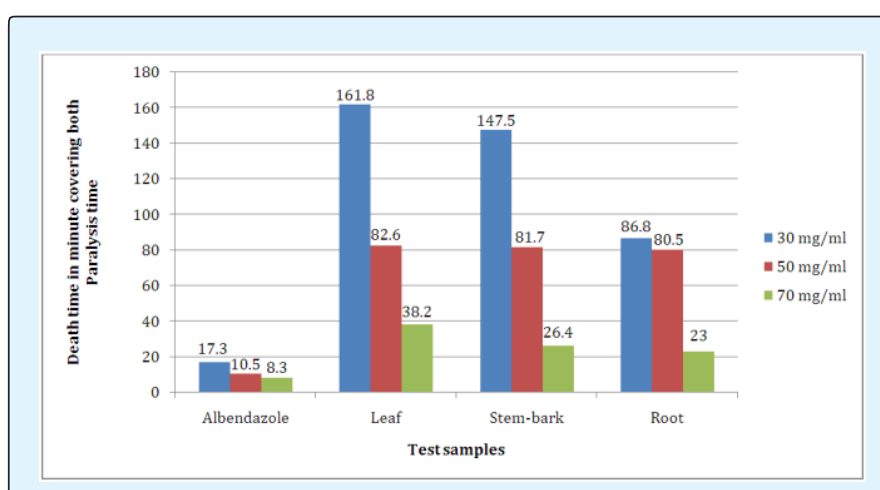

Figure 2B: Death time covering the Paralysis time for the Standard and Test Samples at Different Concentrations.

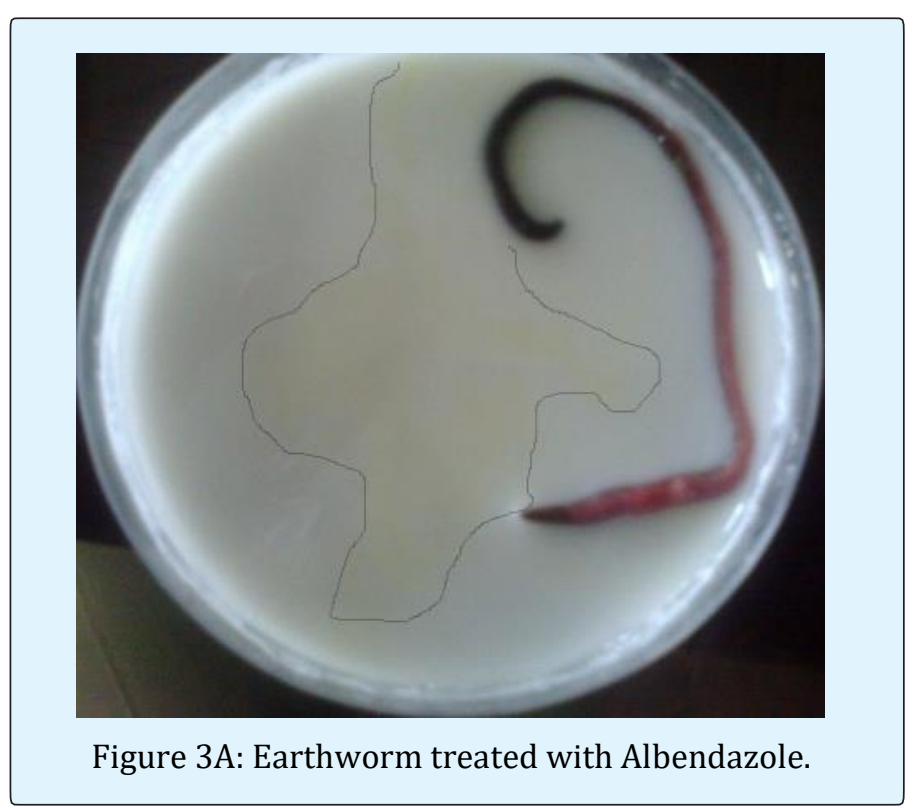

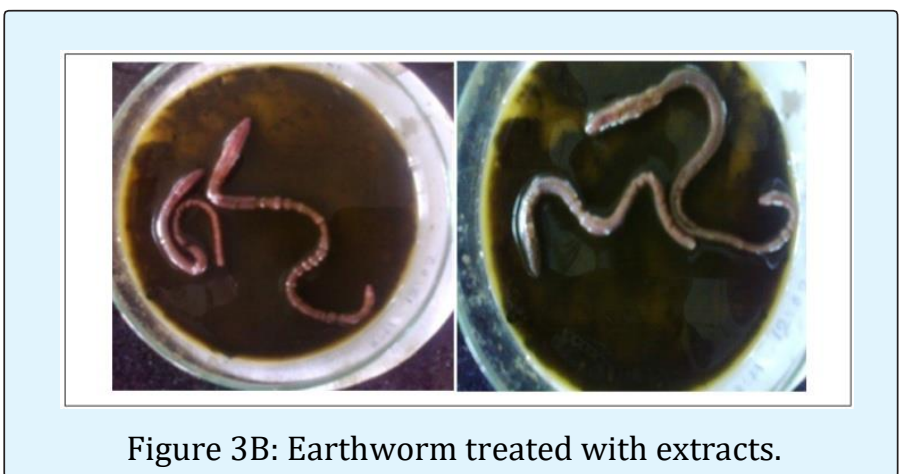

\section{Discussion}

Because of the relative high cost of in vivo tests, in vitro tests have been used for initial screening of plant extracts for their anthelmintic activity [36]. Although adult worms are the major target for chemotherapeutic studies, due to difficulty in raising these parasites in continuous culture, in vitro tests using free living stages of parasitic worms have been used to evaluate the anthelmintic activity of new plant compounds $[37,38]$.

From the results obtained in this study, it can be observed that the methanolic extracts of leaf, stem-bark and the root of Vernonia amygdalina showed anthelminthic with both parasitistatic and parasiticidal effect. The effect obtained from this study is concentration dependent, indicating that the static and cidal effect time of the extracts decreases with increase in concentration as represented in figures $2 \mathrm{~A} \& 2 \mathrm{~B}$. The root extract gave the least paralysis and death times in comparison with the leaf and stem-bark parts.

Anthelmintic medications currently in use has different mechanisms of action which include Tubulin binding and Cellular disruption, Nicotinic-like agonists, Acetylcholine esterase inhibitors, GABA agonists, $\mathrm{GluCl}^{-}$potentiators, Enhance calcium permeability and Proton ionophores. Albendazole which is the standard medication used in this experiment works by causing degenerative alterations in the intestinal cells of the worm by binding to the colchicine-sensitive site of $\beta$-tubulin, thus inhibiting its polymerization or assembly into microtubules (it binds much better to the $\beta$-tubulin of parasites than that of mammals) [39]. Discharged cytoplamic content of the Adult worm can be observed in figure 3A. From figure 3B, it can be suggested that the plant extracts act by enhancing calcium ions permeability, which induces contraction of the parasites, resulting in paralysis in the contracted state. 


\section{Open Access Journal of Pharmaceutical Research}

The ripples observed on the surfaces of the earthworms treated with the extracts in figure $3 \mathrm{~B}$ are similar to the effect of praziquantel on schistosomes. When adult schistosome is treated with praziquantel, the muscles of the schistosome contract because of druginduced influx of $\mathrm{Ca}^{++}$. Changes in the schistosome tegument include small holes and balloon-like structures and exposure of hidden parasite antigens, resulting in the binding of antibodies and phagocytes [40]. It is suspected that the components of the plant extracts may have similar mechanism of action, but further studies on the mechanism of action.

\section{Conclusion}

In conclusion, this study on methanolic extracts of different parts of Vernonia amygdalina provides evidences for its anthelmintic activity which could partly contribute to its ethno medical use. The leaf is mostly used in ethnomedicine, but with this study, it can be observed that other parts of it can also be used if available. However, further investigation is required on the stem-bark to isolate the active constituents responsible for this activity and to elucidate the possible mechanism of action. The stem-bark is suggested because of the economic impact of using the leaf, since it majorly serves as vegetable in the environment it was collected from and the root though has the best activity but for environment impact of uprooting a small plant and fear of extinction should not be used without a better reason.

\section{References}

1. WHO (2017) Neglected Tropical Diseases.

2. WHO (2016) Neglected Tropical Diseases. WHO convenes experts to sustain progress against soiltransmitted helminthiases and Schistosomiasis.

3. WHO (2007) Report of the WHO Expert Consultation on Foodborne Trematode Infections and Taeniasis/Cysticercosis. Vientiane, Lao People's Democratic Republic 12-16 October 2009.

4. Centre for Disease Control and Prevention (2017) Neglected Tropical Diseases.

5. WHO (2017) Helminthiasis. Special Programme for Research and Training in Tropical Diseases (TDR).

6. Chevella SR, Kunchavarapu S, Afreen F, Katukuri R. Devi MS (2017) Comparative Study on Anthelmintic Activity of Musa acuminata (Peel, Leaf) and Ricinuscommunis (Stem, Seed). IJPRS 6(2): 28-31.
7. Hajra S, Mehta A, Pandey P (2012) In Vitro Anthelmintic Activity of Swieteniamahagoni seed extracts against Pheretima posthuma. Int J Pharm Sci Rev Res 12(1): 111-113.

8. Coles GC (1997) Nematode control practices and anthelmintic resistance on British sheep farms. Vet Rec 141(4): 91-93.

9. Geert S, Dorny P (1995) Anthelmintic resistance in helminthes of animals of man in the tropics. Bullet des Sean Academ Royal des Sci Dutre Mer 41(3): 401424.

10. Tagbota S, Townson S (2001) Antiparasitic properties of medicinal plants and other naturally occurring products. Adv Parasitol 50: 199-295.

11. Sondhi SM, Shahu R, Magan A (1994) Anti-Amoebic and Anthelmintic Evaluation of Heterocyclic Compounds Containing Nitrogen and/or Sulphur. Indian Drugs 31(7): 317-320.

12. Hammond JA, Fielding D, Bishop SC (1997) Prospects for plant anthelmintics in tropical veterinary medicine. Vet Res Commun 21(3): 213-228.

13. Waller PJ, Bernes G, Thamsborg SM, Sukura A, Richter $\mathrm{SH}$, et al. (2001) Plants as de-worming agents of livestock in the Nordic countries: historical perspective, popular beliefs and prospects for the future. Acta Vet Scand 42(1): 31-44.

14. Liu ZL, Liu JP, Zhang AL, Wu Q, Ruan Y, et al. (2011) Chinese herbal medicines for hypercholesterolemia. Cochrane Database Syst Rev 7: CD008305.

15. Xu HB, Jiang RH, Chen XZ, Li L (2012) Chinese herbal medicine in treatment of diabetic peripheral neuropathy: A systematic review and meta-analysis. J Ethnopharmacol 143(2): 701-708.

16. Hon KL, Ma KC, Wong Y, Leung TF, Fok TF (2005) A survey of traditional Chinese medicine use in children with atopic dermatitis attending a paediatric dermatology clinic. J Dermatolog Treat 16(3): 154157.

17. Li ZH, Wan JY, Wang GQ, Zhao FG, Wen JH (2013) Identification of compounds from Paris polyphylla (ChongLou) active against Dactylogyrus intermedius. Parasitology 140(8): 952-958.

18. Zhu L, Dai JL, Yang L, Qiu J (2013) In vitro ovicidal and larvicidal activity of the essential of Artemisia lancea 


\section{Open Access Journal of Pharmaceutical Research}

against Haemonchus contortus (Strongylida). Vet Parasitol 195(1-2): 112-117.

19. Hrckova G, Velebny S (2013) Pharmacological Potential of Selected Natural Compounds in the Control of Parasitic Diseases. Parasitic helminths of humans and animals: health impact and control pp: 29-99.

20. Roeber F, Kahn L (2014) The specific diagnosis of gastrointestinal nematode infections in livestock: Larval culture technique, its limitations and alternative DNA-based approaches. Vet Parasitol 205(3-4): 619-628.

21. Eguale T, Tadesse D, Giday M (2011) In vitro anthelmintic activity of crude extracts of five medicinal plants against egg-hatching and larval development of Haemonchus contortus. J Ethnopharmacol 137(1): 108-113.

22. Hoste H, Jackson F, Athanasiadou S, Thamsborg SM, Hoskin SO (2006) The effects of tannin-rich plants on parasitic nematodes in ruminants. Trends Parasitol 22(6): 253-261.

23. Kaewintajuk K, Cho PY, Kim SY, Lee ES, Lee HK, et al. (2010) Anthelmintic activity of KSI-4088 against Caenorhabditiselegans. Parasitol Res 107(1): 27-30.

24. Chikezie PC,Ojiako, Nwufo KC (2015) Overview of Anti-Diabetic Medicinal Plants: The Nigerian Research Experience. J Diabetes Metab 6: 546.

25. Afolayan AJ, Sunmonu TO (2010) In vivo Studies on Antidiabetic Plants Used in South African Herbal Medicine. J Clin Biochem Nutr 47(2): 98-106.

26. Egedigwe CA (2010) Effect of dietary incorporation of Vernonia amygdalina and Vernonia colorata on blood lipid profile and relative organ weights in albino rats (Thesis). Department of Biochemistry, Michael Okpara University of Agriculture, Umudike, Nigeria.

27. Kokwaro J (2009) Medicinal Plants of East Africa (Third edition), University of Nairobi Press, Nairobi.

28. Yeap SK, Wan YH, Boon KB, Woon SL, Huynh K, et al. (2010) Vernonia amygdalina, an ethnoveterinary and ethnomedical used green vegetable with multiple bioactivities. J Med Plant Res 4(25): 2787-2812.

29. Jisaka M, Ohigashi H, Takagaki T, Nozaki H, Tada T, et al. (1992) Bitter steroid glucosides, Vernoniosides A1, $\mathrm{A} 2, \mathrm{~A} 3$ and related $\mathrm{B} 1$ from a possible medicinal
plant-Vernonia amygdalina used by wild chimpanzees. Tetrahedron 48 (4): 625-632.

30. Huffman MA, Seifu M (1989) Observations on the illness and consumption of possibly medicinal plant Vernonia amygdalina (Del.) by a wild chimpanzee in Mahale Mountains National Park, Tanzania. Primates 30(1): 51-63.

31. Regassa A (2000) The use of herbal preparations for tick control in western Ethiopia. J S Afr Vet Assoc 71(4): 240-24.

32. Igweh AC, Onabanjo AO (1989) Chemotherapeutic of Annonasenegalensis in Trypanosomabrucei. Ann Trop Med Parasitol 83(5): 527-534.

33. Sahpaz S, Bories C, Loiseau PM, Cortes D, Hocquemiller R, et al. (1994) Cytotoxic and antiparasitic activity from Annona senegalensis seeds. Plant Med 60(6): 538-540.

34. Kupchan SM, Hemingway RJ, Karim A, Werner D (1969) Tumor inhibitors. XLVII. Vernodalin and Vernomydin, two new cytotoxic sesqueterpene lactones from Vernonia amygdalina Del. J Org Chem 34(12): 3908-3911

35. Jisaka M, Ohigashi $H$, Takagaki $T$, Nozaki $H$, Tada $T$, et al. (1992) Bitter steroid glucosides, Vernoniosides A1, A2, A3 and related B1 from a possible medicinal plant-Vernonia amygdalina used by wild chimpanzees. Tetrahedron 48 (4): 625-632.

36. Lacey E, Redwin JM, Gill JH, Demargheriti VM, Waller PJ (1990) A larval development assay for the simultaneous detection of broad spectrum anthelmintic resistance. Resistance of Parasites to Antiparasitic Drugs. Round Table Conference held at the 7th International Congress of Parasitology. MSDAgvet, Rajway, New York 177-184.

37. Geary TG, Sangster NC, Thompson DP (1999) Frontiers in anthelmintic pharmacology. Vet. Parasitol 84(3-4): 275-295.

38. Asase A, Oteng-Yeboah AA, Odamtten GT, Simmonds MS (2005) Ethnobotanical study of some Ghanaian anti-malarial plants. J Ethnopharmacol 99(2): 273279.

39. Albendazole. https://www.drugs.com/monograph/albendazole.ht $\mathrm{ml}$

40. (2015) Drugs to Treat Parasitic Infections. 